\title{
PENGEMBANGAN SOFSKILL TEKNIK PENGELASAN BAGI GENERASI MUDA USIA PRODUKTIF UNTUK MEMBUAT HOME INDUSTRI MELALUI PELATIHAN PROSES PENGELASAN
}

\section{THE DEVELOPMENT OF SOFTSKILL WELDING TECHNIC FOR PRODUCTIVE YOUNG GENERATION TO MADE HOME INDUSTRY BY TRAINING WELDING PROCESS}

\author{
Oleh: \\ Yeni Suhartini ${ }^{1)}$, Anizar Indriani ${ }^{1)}$, dan Muhammad Syaiful ${ }^{2)}$ \\ ${ }^{1)}$ Program Studi Teknik Elektro Fakultas Teknik Universitas Bengkulu \\ 2) Jurusan Teknologi Ilmu Pertanian Fakultas Pertanian Universitas Bengkulu
}

\begin{abstract}
Welding processing is the process to make some part of metal become a unit by using heat. Some application of welding process can be seen at the fence, truss, door, gate and etc. The fence, trellis windows and doors and a gate are made from iroin highly prevalent today. The Iron fence, trellis for windows and doors as well as the gate is made and designed to make home become beautiful. The fencing, railing, and gating are using welding machines to connect and decorate the desired shapes. Expertise in designing and welding of products are very important to meet the requirement of customers. As seen from the shape and style of fences and trellises shows the state of community identity in the area. Expertise to design and design as well as the use of welding machines can be obtained by the public through formal education in Vocational High School of Engineering and informal (BLK). In addition to the society through education can not study the processes undertaken to make tools or products such as fences, trellises and the gate. It is very harmful for people who do not have a chance to get a formal education or informal. Through community service, which is part of the Tri Dharma College conducted the transfer of knowledge to the people who did not get a formal or informal education to practice making these objects with the welding process. With this training adds insight and knowledge society. From the results of this training is seen that people who can not follow the formal and informal education have a high desire to attend this training. This is to improve the economy and living standards by utilizing the welding knowledge to create new jobs or working with existing workshops.
\end{abstract}

Keywords: Welding Technique, Productive Age, Training

\section{PENDAHULUAN}

Pendidikan adalah modal utama bagi suatu bangsa dalam upaya meningkatkan kualitas sumberdaya manusia yang dimilikinya. Sumberdaya manusia yang berkualitas akan mampu mengelola sumber daya alam dan memberi layanan secara efektif dan efisien untuk meningkatkan kesejahteraan masyarakat dan meningkatkan taraf hidup. Oleh karena 
itu, hampir semua bangsa berusaha meningkatkan kualitas pendidikan yang dimilikinya, termasuk Indonesia secara umun dan Propinsi Bengkulu secara khususnya. Kualitas sumberdaya manusia dapat dilihat dari kemampuan atau kompetensi yang dimiliki baik melalui jalur formal dan nonformal. Kompetensi dan kemampuan yang dimiliki oleh manusia selanjutnya akan diterapkan secara nyata dalam kehidupan sehari-hari untuk memenuhi kebutuhan hidup dan kerja.

Salah satu model peningkatan kualitas hidup dapat diperoleh melalui jalur pelatihan dan penyuluhan yang membutuhkan waktu yang singkat sehingga menguasai skill lapangan untuk diterapkan pada masyarakat. Peserta dibina dan diarahkan dengan metode yang lebih efektif dan tepat sasaran dan berorientasi pada memanajemen praktek. Tujuannya adalah setelah kegiatan pelatihan dilakukan diharapkan peserta pelatihan dapat memanajemen diri sendiri dan menerapkan skill yang diperolehnya dengan membuka lapangan kerja baru dalam bentuk wirausaha.

Berdasarkan data yang diperoleh di lapangan Karang Taruna Hizbul Watthan di desa Talang Empat Kecamatan Karang Tinggi Kabupaten Bengkulu Tengah, jumlah pemuda putus sekolah dan pada usia produktif kerja berkisar 120 orang. Jumlah pemuda putus sekolah yang cukup besar, bila dibiarkan dapat menyebabkan penumpukan pengangguran dan menimbulkan masalah sosial baru. Disatu sisi pertumbuhan kota dan tingginya permintaan akan pembangunan Kabupaten Bengkulu Tengah dan di desa Talang Empat Kecamatan Karang Tinggi khususnya, dapat menjadi peluang membuka lapangan kerja baru dan berwirausaha yang responsif untuk meraih kesempatan tersebut. Namun belum ada tindakan nyata baik dari pemerintah maupun tokoh masyarakat dan pengusaha. Akibatnya kebanyakan orderan yang diminta untuk pembangunan gedung pemerintahan, perumahan dan perhotelan serta pembangunan lainnya diberikan kepada sekelompok orang saja. Berdasarkan kenyataan ini, maka melalui program pengabdian kepada masyarakat untuk memberikan Program Pelatihan Teknik Pengelasan untuk pengembangan Softskill Bagi Pemuda Putus Sekolah dan Siswa/i SMK sehingga dapat membuka lapangan kerja baru di Kabupaten Bengkulu Tengah.

Pelatihan ini dapat membekali peserta untuk mampu mengelas menghasilkan produk berupa terali rumah dengan berbagai model, kombinasi dan variasi; mampu membuat pagar rumah, perkantoran, perhotelan, tangga besi; mampu mengelas kendaraan atau asembly otomotif; mampu mengelas tower, mampu membuat produk hasil pengelasan berupa barang lainnya. Pelatihan ini dapat membuka cakrawala dan modal bekerja bagi peserta menciptakan lapangan kerja baru.

Bekal ketrampilan dan melatih remaja putus sekolah dapat membuka peluang usaha yang dapat dilakukan terkait dengan kebutuhan akan produk yang dapat dihasilkan dari pelatihan pengelasan berupa pembuatan terali, tower besi serta pagar (rumah, perkantoran, perhotelan), membuat asembly otomotif, barang-barang perabot rumah tangga, kantor, serta hasil pengelasan lainnya. 
Kondisi ini membuka peluang usaha pengelasan yang dapat menghasilkan produkproduk barang jadi yang dapat digunakan :

1. Pembuatan Terali Besi menggunakan Besi Pejal, Hollow serta stainless,

2. Pembuatan pagar, tower, perabot rumah tangga berupa kursi, meja, lemari, rak-rak buku, serta etalase,

3. Pembuatan asembly otomotif.

Masalah pokok yang ingin dipecahkan dalam kegiatan ini adalah bagaimana memberdayakan anak sekolah dan remaja putus sekolah Karang Taruna Hizbul Watthan di Desa Talang Empat Kecamatan Karang Tinggi Kabupaten Bengkulu Tengah. Adapun yang menjadi permasalahan adalah:

1. Bagaimana mengupayakan keterampilan bagi anak sekolah dan remaja putus sekolah.

2. Bagaimana membuka lapangan pekerjaan yang layak bagi remaja putus sekolah Karang Taruna Hizbul Watthan di Desa Talang Empat Kecamatan Karang Tinggi Kabupaten Bengkulu Tengah.

3. Bagaimana meningkatkan pendapatan keluarga dengan cara yang profesional dan tenaga terampil.

4. Bagaimana meningkatkan sumber daya manusia remaja putus Karang Taruna Hizbul Watthan di Desa Talang Empat Kecamatan Karang Tinggi Kabupaten Bengkulu Tengah.

\section{Teori Pengelasan}

Pengelasan merupakan suatu proses penyambungan dua buah logam atau lebih menjadi satu dengan memanfaatkan panas atau tekanan. Atau didefinisikan dengan tarik menarik antara atom untuk membentuk suatu ikatan dimana permukaan baru yang terbentuk menjadi bebas dari oksida.

Proses pengelasan ada 3 macam yaitu :

1. Pengelasan tekan,

2. Pengelasan dengan pemanasan logam pengisi,

3. Patri.

Pengelasan tekan merupakan proses penyatuan logam dengan cara dipanaskan dan disatukan. Penyambungan dengan memanaskan material logam hingga mencair dengan media pemanas busur listrik atau semburan api disebut dengan pengelasan cair. Pematrian merupakan penyambungan loigam dengan menggunakan paduan logam dengan titik cair rendah seperti pemanfaatan timah dan logam lainnya.

Berdasarkan sumber panas dan cara pengelasan terdiri atas :

1. Mekanik

2. Listrik

3. Kimia

4. Pengelasan tekanan (Pressure Welding)

5. Pengelasan Cair (Fusion welding) 


\section{Sambungan las}

Penyambungan logam melalui proses pengelasan harus menghasilkan sambungan dengan kekuatan yang baik dimana hal ini dapat dilakukan dengan memilih bentuk kampuh las (Arifin, 1997). Jenis sambungan las dan bentuk kampuhnya dapat dilihat pada Gambar 1 dan 2, dimana jenis sambungannya adalah sambunga tumpu, sambungan sudut, sambungan tumpang, sambungan T, sambungan tekuk. Untuk kampuh terdiri atas kampuh persegi, kampuh $\mathrm{V}$, kampuh lereng tunggal dan $\mathrm{K}$ dan kampuh $\mathrm{U}$ tunggal dan ganda.

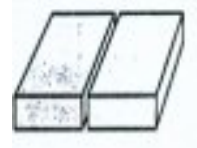

(a)

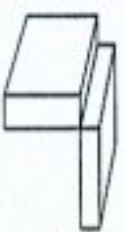

f:

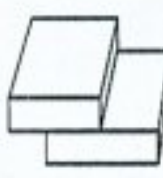

(c)

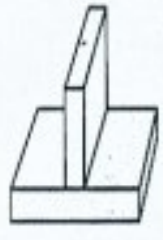

(d)

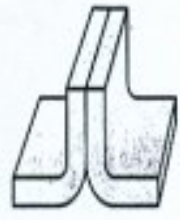

a. Sambungan tumpu (butt joint).

b. Sambungan sudut (corner joint)

c. Sambungan tumpang (lap joint)

d. Sambungan T (tee joint)

e. Sambungan tekuk (edge joint)

(E)

Gambar 1. Jenis Sambungan Las (Harsono Dan Okumura, 2008)

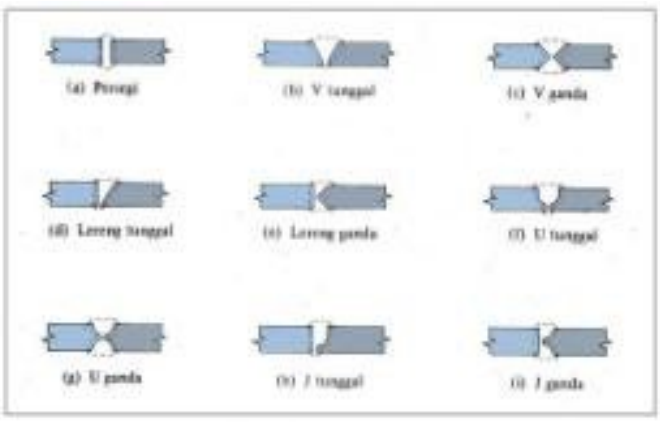

Gambar 2. Jenis-jenis Kampuh Las (Harsono dan Okumura, 2008)

\section{Proses pengelasan}

Berbagai proses pengelasan telah dikembangkan, tergantung pada cara pemanasan dan peralatan yang digunakan., proses pengelasan yaitu :

1. Pengelasan patri terdiri atas patri nyala, celup, tahanan, infra merah, dapur, induksi.

2. Pengelasan tempa terdiri atas pengerjaan tangan dan pengerjaan mesin (rol dan pukul, die).

3. Pengelasan gas terdiri dari udara-asitelin, oksiasitelin, oksihidrogen dan tekanan.

4. Pengelasan tahanan berupa las titik, kampuh, proyeksi, tumpu, nyala dan perkussion.

5. Pengelasan induksi dengan frekuensi tinggi.

6. Pengelasan Busur.

7. Elektroda karbon (terlindung terdiri atas busur terlindung, titik busur, hidrogen atom, gas inert, busur terendam, lantak, terak elektro dan tanpa lindungan berupa logam polos lantak). 


\section{Elektroda}

Pengelasan memerlukan kawat las (elektroda) yang terdiri dari inti terbuat dari logam yang dilapisi dari campuran zat kimia. Gambar 3 menunjukan bentuk elektroda (kawat las).

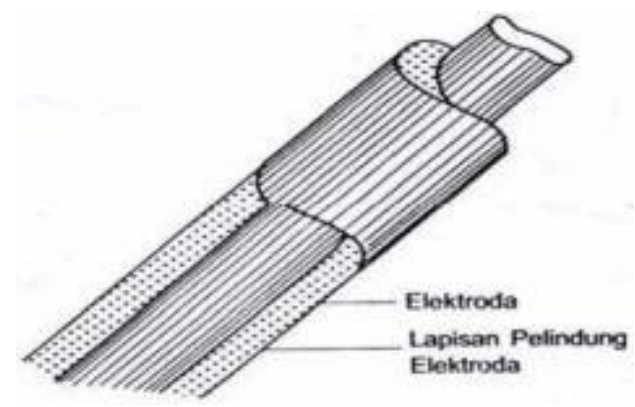

Gambar 3. Elektroda Las (Bintoro, 2005)

Elektroda memiliki bagian berselaput dan tidak berselaput yang berguna sebagai bagian untuk dijepit pada mesin las. Fluks (lapisan elektroda) berguna untuk melindungi logam cair dari lingkungan luar seperti udara, menstabilkan busur dan unsur paduan.

Kawat elektroda terdiri atas elektroda untuk baja lunak, baja karbon tinggi, baja paduan, besi tuang, dan logam non ferro dimana bahan elektroda harus sama sifatnya dengan logam yang dilas (Suharto, 1991). Penamaan elektroda diatur berdasarkan standar AWS (American Welding Society) dan ASTM (American SocietyTesting Material) misalnya E6013 memiliki arti E (elektroda untuk las busur listrik), 60 (nilai tegangan tarik minimum hasil pengelasan dikalikan dengan 1000 psi $\left(60.000 \mathrm{lb} / \mathrm{in}^{2}\right)$ atau $\left.42 \mathrm{~kg} / \mathrm{mm}^{2}\right)$, 1(posisi pengelasan), 1 (pengelasan semua posisi) dan 3 (jenis selaput elektroda Rutil-Kalium dan pengelasan dengan arus AC atau DC).

\section{Teknik Pengelasan}

Teknik pengelasan meliputi metode pengelasan, posisi pengelasan, proses pengelasan dan finishing hasil pengelasan. Berdasarkan posisi pengelasan terdiri atas posisi bawah tangan, tegak, datar dan posisi atas kepala. Posisi di bawah tangan merupakan cara pengelasan dibawah tangan pada permukaan rata/datar dengan kemiringan elektroda las $10^{\circ}-20^{\circ}$ dan $70^{\circ}-80^{\circ}$. Posisi tegak merupakan posisi dengan arah keatas dan bawah dimana pengelasan ini sulit dengan emiringan elektroda sekitar $10^{\circ}-15^{\circ}$ dan $70^{\circ}-$ $85^{\circ}$. Pengelasan horizontal atau rata dilakukan dengan kedudukan benda tagak dan arah elektroda horizontal dengan kemiringan sekitar $5^{\circ}-10^{\circ}$ dan $70^{\circ}-80^{\circ}$. Posisi pengelasan yang sangat sulit adalah pengelasan diatas kepala dengan kemiringan sekitar $5^{\circ}-20^{\circ}$ terhada garis vertikal dan $75^{\circ}-85^{\circ}$ terhadap benda kerja. 


\section{Komponen Mesin Las}

Mesin las terdiri dari beberapa komponen yaitu :

1. Tombol pemutar berfungsi untuk menghidupkan mesin las (transformator).

2. Pengatur arus berfungsi mengatur besarnya kuat arus.

3. Kutub positif dan negatif.

4. Penjepit benda kerja yang akan dilas.

5. Penjepit elektroda yang digunakan sebagai logam pengisi.

6. Klem tiga fasa berfungsi untuk pengaturan arus jauh dari mesin las

Untuk las busur manual alat utamanya adalah :

1. Kabel tenaga

2. Trafo las

3. Kabel elektroda dan kabel massa

4. Pemegang elektroda danpenjepit massa

Hal-hal yang harus diperhatikan dalam proses pengelasan adalah :

- Tegangan busur las.

- Besar arus listrik.

- Polaritas listrik.

- Besarnya penembusan dan penetrasi

Alat utama proses pengelasan terdiri atas nozzle, dudukan nozzle dan collet, collet, tungsten, back cap, argon regulator seperti terlihat pada Gambar 4.

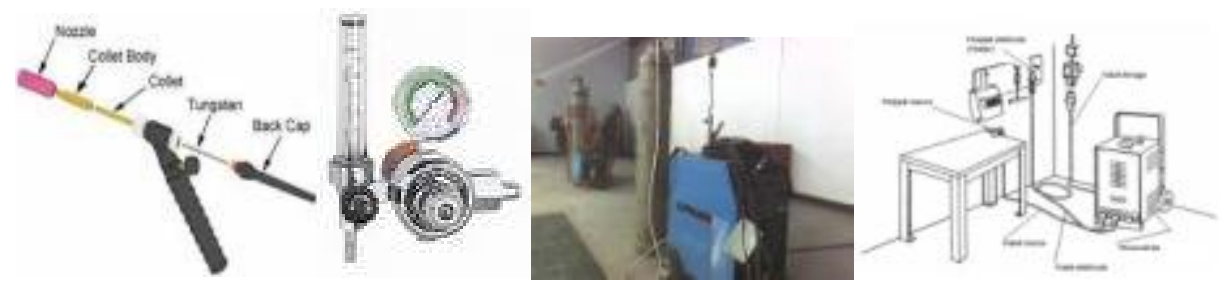

Gambar 4. Alat Utama Mesin Las

Selain alat utama alat lain yang diperlukan dalam proses pengelasan adalah alat bantu dan alat keselamatan kerja. Alat bantu terdiri atas ragum, kikir, gergaji, penitik, penggores, palu, sikat baja, penggaris, siku dan gerinda tangan. Alat keselamatan kerja meliputi sarung tangan, kacamata, helm, sepatu las dan pelindung dada seperti yang terlihat pada Gambar 5.
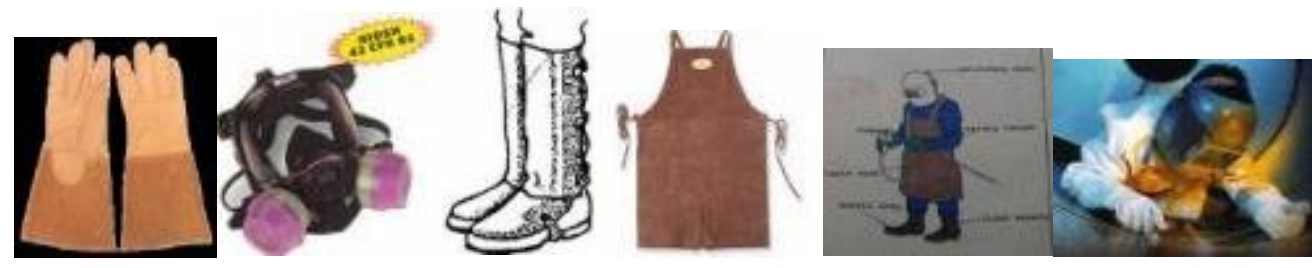

Gambar 5. Alat Keselamatan Kerja 


\section{Gambar dan Simbol Las}

Gambar dan simbol las merupakan bagian utama yang harus dipahami untuk pengguna mesin las. Jika hal ini tidak dipahami maka hasil proses pengelasan tidak akan baik dan sesuai dengan yang diinginkan konsumen. Dimana produk menjadi gagal dan tidak diterima oleh konsumen. Contoh gambar dan simbol las dapat dilihat pada Gambar 6, dimana pada Gambar 6 terlihat jenis proses pengelasan SMAW dengan penempatan pipa miring 45 derajat pada meja, jenis kampuh $\mathrm{V}$, arah dari bawah ke atas dan benda yang dilas diam dan hasil pengelasan cembung.
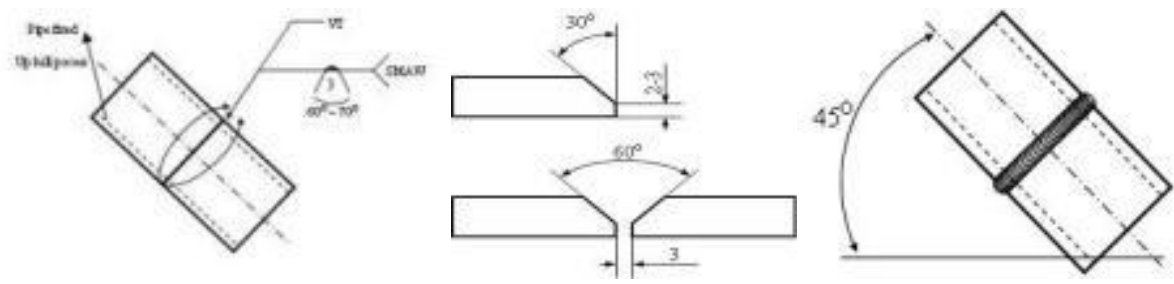

Gambar 6. Gambar dan Simbol Las

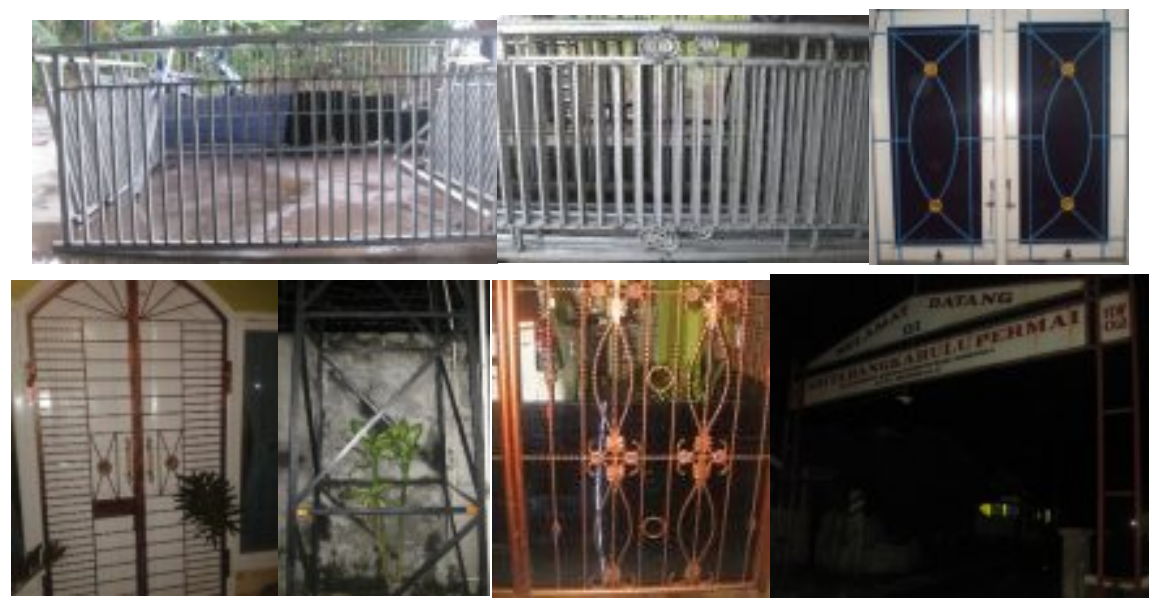

Gambar 7 Jenis Bahan Las dan Bentuk Produk Las

\section{Jenis Bahan/Material Las dan Produk Las}

Selain gambar dan simbol las, yang perlu diperhatikan adalah bahan atau material benda yang dilas. Yang terdiri atas bahan ferro dan non ferro serta unsur paduan. Gambar 7 menunjukan jenis bahan atau material las yang akan dibuat yaitu pagar, teralis, tower, besi hollow, besi pejal dan lainnya.

\section{Tujuan Pelatihan}

Program Pelatihan Teknik Pengelasan untuk pengembangan Softskill Bagi PemudaPutus Sekolah dan Siswa/i SMK di Kabupaten Bengkulu Tengah. Adapun Tujuan kegiatan pelatihan dilaksanakan adalah : 
1. Untuk mendapatkan perubahan yang secara sistematis bagi putus sekolah yang sama sekali belum memiliki keterampilan dalam mengembangkan softskill Teknik Pengelasan sampai menghasilkan produk-produk asembly melalui pelatihan pengelasan bagi remaja putus sekolah.

2. Meningkatkan ketrampilan dan pola pikir sumber daya manusia remaja putus sekolah dan anak sekolah di bidang Program Pelatihan Teknik Pengelasan untuk pengembangan Softskill Bagi Pemuda Putus Sekolah dan Siswa/i SMK sehingga dapat membuka lapangan kerja baru di Kabupaten Bengkulu Tengah.

3. Dapat mengurangi pengangguran di Kecamatan Karang Tinggi kabupaten Bengkulu Tengah Propinsi Bengkulu.

\section{Manfaat Pelatihan}

Manfaat Pelatihan yang dapat diperoleh dari kegiatan ini adalah:

1. Meningkatkan sumber daya manusia dalam ketrampilan pembuatan produk-produk pengelasan seperti terali rumah, perkantoran, perhotelan; pagar rumah, pagar perkantoran; tower-tower serta banyaknya produk yang menggunakan teknik pengelasan, bagi anak sekolah dan remaja putus sekolah.

2. Membuat anak sekolah dan remaja memiliki pengetahuan wawasan keterampilan dalam bidang Teknik Pengelasan.

3. Meningkatkan bekal bagi anak sekolah dan remaja putus sekolah dalam mencari dan menciptakan lapangan pekerjaan.

4. Dengan telah dimiliki pekerjaan yang dapat menunjang penghasilan keluarga, serta mengurangi pengangguran.

\section{METODE PENGABDIAN}

Metode pelaksanaan program pengabdian masyarakat ini adalah dengan pelatihan penggunaan mesin las untuk membuat produk seperti pagar besi, teralis pintu atau jendela dan gapura. Dalam pelatihan ini difokuskan pada dasar pengelasan agar mudah memberikan pengetahuan bagi masyarakat awam. Untuk sasaran dan lokasi penerapan pengabdian masyarakat ini adalah pada Pemuda Karang Taruna Hizbul Watthan di desa Talang Empat Kecamatan Karang Tinggi dengan melibatkan 30 orang dengan berbagai tahapan sebagai berikut :

\section{a. Tahapan Rencana tindakan}

Penerapan teknologi ini menggunakan metode pendekatan pelatihan campuran. Tahap pertama dengan menggunakan teknik inovasi dan kreatifitas, tahap kedua dengan menggali kemampuan dasar, tahap ketiga dan kempat dengan melakukan uji langsung menghasilkan produk dan melakukan Perawatan/pemeliharaan. Subjek pengabdian dalam hal ini adalah remaja putus sekolah dan anak sekolah SMK, dengan langkahlangkah kegiatan sebagai berikut : 
1. Kegiatan ini diawali dengan menginterview peserta untuk mengetahui pemahaman mereka tentang Teknik Pengelasan dan proses Pengelasan.

2. Pembimbing memberi pengarahan dan materi tentang Teknik Pengelasan.

3. Berdasarkan data hasil interview dan pengamatan sebelumnya pembimbing mendiskusikan tentang pemahaman Teknik pengelasan peserta pelatihan.

4. Pembimbing dan peserta berdiskusi rencana keterampilan untuk pertemuan berikutnya.

5. Pembimbing memberi teori dan mempraktekkan teori-teori tersebut

6. Pembimbing memberi kesempatan para peserta untuk berpraktekum perorangan

7. Pembimbing mengamati kemampuan yang telah dimiliki peserta

8. Menetapkan keberhasilan tahapan awal dalam bereksperimen

\section{b. Tahapan Pelaksanaan Tindakan}

Tahapan pelaksanaan tindakan meliputi :

1. Pada tahap pelaksanaan lanjutan dimulai dengan pemberian materi dan informasi Tentang Teknik Pengelasan dan permasalahan yang sering timbul pada saat melakukan Pengelasan.

2. Pembimbing memberi beberapa contoh dalam pelatihan Teknik Pengelasan.

3. Pembimbing memberi pengarahan sekaligus eksperimen Teknik Pengelasan.

\section{c. Tahapan Observasi}

Tahapan observasi meliputi :

1. Pada tahap observasi, kegiatan yang dilakuakan pembimbing adalah mengamati setiap tindakan peserta dalam berekspereimen dan melakukan ujian tertulis tentang pengetahuan yang telah dimiliki.

2. Pembimbing bersama dengan peserta mendiskusikan permasalahan Teknik Pengelasan.

3. Pembimbing kembali melakukan evaluasi secara tertulis terhadap tindakan yang telah dilakukan peserta.

4. Pembimbing mengidentifikasi hal-hal yang telah dicapai oleh peserta

5. Pembimbing kembali mendiskusikan penyebab terjadinya kekurangandan merumuskan kembali cara memperbaiki hal-hal yang kurang berhasil.

\section{d. Tahapan Metode Pengumpulan Data Dan Analisa Data}

1. Pengumpulan data tentang proses yang dicapai digunakan observasi dan wawancara

2. Observasi dilakukan untuk mengamati keterampilan peserta secara individual

3. Wawancara digunakan untuk mengetahui tanggapan peserta terhadap keterampilan yang telah dicapai.

4. Data yang telah dikumpulkan akan dianalisa secara deskriptif dan presentase, yaitu suatu analisa data, dimana temuan temuan temuan didiskripsikan kedalam pernyataan-pernyataan. Suatu kesimpulan dapat diambil berdasarkan kecenderungan yang bersifat umum. 
Untuk mengukur keberhasilan kegiatan maka dilakukan evaluasi dengan tahapan sebagai berikut :

1. Pengumpulan data tentang proses yang dicapai digunakan observasi dan wawancara

2. Observasi dilakukan untuk mengamati keterampilan peserta secara individual

3. Wawancara digunakan untuk mengetahui tanggapan peserta terhadap keterampilan yang telah dicapai.

4. Data yang telah dikumpulkan akan dianalisa secara deskriptif dan presentase, yaitu suatu analisa data, dimana temuan temuan-temuan didiskripsikan kedalam pernyatanpernyataan. Suatu kesimpulan dapat diambil berdasarkan kecenderungan yang bersifat umum.

5. Data tentang keterampilan akan dikategorikan rendah, sedang, dan tinggi. Kategori rendah jika tingkat keberhasilannya mencapai kurang dari $20 \%$, sedang jika tingkat keberhasilannya adalah 40\% - 80\%, tinggi jika 74\% - 99\%.

6. Diharapkan setelah pelatihan ini akan membuka lapangan kerja baru serta mendapatkan pekerjaan dengan kemampuan yang dimiliki lebih kurang $75 \%$.

\section{HASIL DAN PEMBAHASAN}

\section{Hasil Pelatihan Proses Pengelasan}

Pelatihan proses pengelasan yang dilakukan melipuit pengenalan alat-alat las yang akan digunakan, produk yang dapat dibuat dengan proses las dan jenis-jenis mesin las yang dapat dimanfaatkan untuk membuat produk tersebut serta alat bantu untuk proses finishing hasil lasan. Gambar 8 menunjukan peralatan las yang digunakan dalam proses pelatihan ini seperti mesin las (Gambar 8a), elektroda (Gambar 8b) dan mesin gerinda tangan untuk proses finishing hasil proses las.

Proses pelatihan dapat dilihat pada Gambar 9, dimana beberapa peserta mencoba melakukan proses penyambungan besi hollow dengan mesin las listrik. Disitu terlihat pentingnya kacamata pelindung untuk menjaga agar mata tidak langsung terkena radiasi dari pancaran atau percikan bunga api pada saat pengelasan. Dari hasil pengelasan yang dilakukan peserta terlihat beberapa peserta sudah dapat menggunakan mesin las untuk membuat atau menyambung suatu benda.

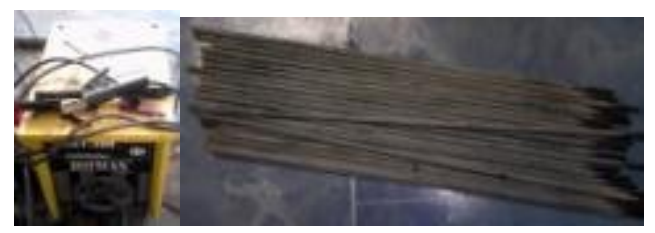

a. Mesin Las dan Elektroda 


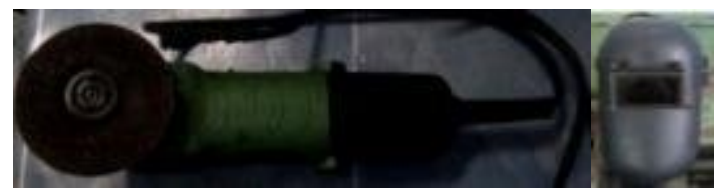

b. Mesin Gerinda Tangan dan Pelindung

Gambar 8. Mesin Las, Mesin Gerinda dan Alat Pelindung

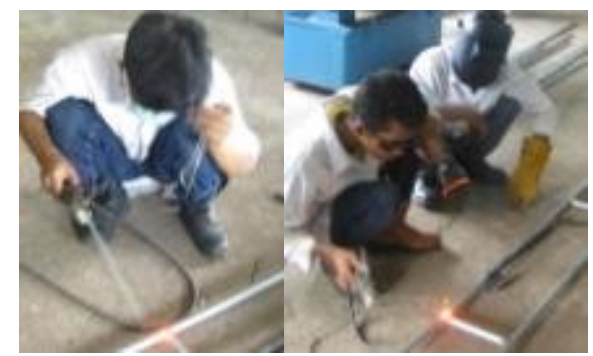

Gambar 9. Proses Pelatihan Pengelasan

\section{Hasil Pelatihan Bagi Masyarakat}

Pelatihan yang telah dilaksanakan dan respon masyarakat dalam mengikuti pelatihan ini sangat besar. Dimana semua peserta terlihat dengan tekun mengikuti arahan yang diberikan. Hal ini mungkin disebabkan oleh keinginan masyarakat untuk mendapatkan pengetahuan yang baru tentang pengelasan dan aplikasinya dilapangan. Dari hasil pelatihan ini masyarakat menginginkan kelanjutan dalam pelatihan ini untuk membuat komponen atau produk las yang lain.

Keinginan masyarakat ini timbul karena melihat banyaknya keuntungan jika bisa menggunakan mesin las untuk membuat sesuatu benda yang berguna dalam kehidupan sehari-hari seperti pembuatan pagar, teralis, papan nama dan lainnya. Selain dapat membuat benda dengan mesin las, pengetahuan pengelasan ini juga akan menambah pemasukan masyarakat dengan cara membuka bengkel kecil atau bergabung dengan bekerja pada bengkel yang sudah ada.

\section{KESIMPULAN DAN SARAN}

\section{Kesimpulan}

Dari pelatihan yang dilakukan dapat ditarik beberapa kesimpulan yaitu:

1. Pelatihan dapat berjalan dengan baik dimana $80 \%$ masyarakat dapat memahami dan mengetahui jenis-jenis las dan proses pengelasan listrik.

2. Masyarakat dapat membuat produk dengan menggunakan mesin las seperti membuat rangka yang sederhana untuk pembuatan tenda atau pagar.

3. Pelatihan ini menghasilkan $80 \%$ peserta dapat menggunakan mesin las untuk membuat suatu produk. 


\section{Saran}

Sebaiknya pelatihan ini dapat dilakukan secara reguler dan kontinu karena masih banyak jenis proses pengelasan yang dapat dimanfaatakan dan dipilih oleh masyarakat desa dalam memberi nilai tambah dari segi skill menggunakan suatu mesin terutama mesin las.

\section{DAFTAR PUSTAKA}

Arifin, S., 1997, Las Listrik dan Otogen, Ghalia Indonesia, Jakarta.

Bintoro, A. Gatot, 2005, Dasar-Dasar Pekerjaan Las, Kanisius, Yogyakarta.

Harsono, Wiryosumarto dan Toshie Okumura, 2008, Teknologi Pengelasan Logam, Pradnya Paramita, Jakarta.

Suharto, 1991, Teknologi Pengelasan Logam, Rineka Cipta, Jakarta. 